\title{
MOBRAL/PAF E O APELO IDEOLÓGICO PARA O SALVACIONISMO EDUCACIONAL: FORÇAS CENTRÍPETAS E CENTRÍFUGAS EM MOVIMENTO* ${ }^{* 1}$
}

\author{
Margareth Correia Fagundes Costa \\ PPGMLS/UESB \\ Livia Diana Rocha Magalhães \\ PPGMLS/UESB
}

\section{Introdução}

Neste texto recuperamos os usos midiáticos realizados pelo Movimento Brasileiro de Alfabetização ${ }^{2}$ /subprograma Alfabetização Funcional (MO$\mathrm{BRAL} / \mathrm{PAF}$ ) por meio do apelo a uma memória social conservadora. Essa memória é ativada através do apelo a signos imagéticos e linguísticos - operações ideológicas - numa tentativa de envolver a sociedade nas ações desse programa, que via na alfabetização condição básica para inserção do Brasil na vida socioeconômica capitalista.

Nesse sentido, mostramos a participação de vários setores da comunidade - forças centrípetas em torno do MOBRAL/PAF, bem como recuperamos propagandas (slogans, canções, jingles, textos, imagens) que se configuram como forças centrífugas direcionadas à comunidade; ora culpabilizando-a pela existência do analfabetismo, ora conclamando-a para a tarefa de alfabetizar.

Tomamos como referência a discussão de Memória Social e Coletiva, com base em (HALBWACHS, 2003, 2004) quando considera que construímos nossa memória de acordo com os valores de uma sociedade - sua "vida moral e material", e com a vivência no conjunto das relações coletivas, nos grupos aos quais pertencemos, pois o indivíduo “[...] não é o indivíduo isolado, é o indiví-

${ }^{*}$ DOI - 10.29388/978-65-86678-62-8-0-f.41-58

${ }^{1}$ Esse texto é um recorte da pesquisa de doutorado sobre o MOBRAL-PAF realizada no Programa de Memória, Linguagem e Sociedade PPGMLS/UESB, desenvolvida por Margareth Correia Fagundes Costa e orientada pela profa. Lívia Diana Rocha Magalhães, na qual analisou-se a cartilha do Movimento Brasileiro de Alfabetização/subprograma Alfabetização Funcional (MOBRAL/PAF). Nessa análise, buscou-se compreender como a memória social (HALBWACHS, 2003, 2004) dos alfabetizandos (as) é acessada e as operações ideológicas ali realizadas. No entanto, nesse artigo, optamos por apresentar investidas ideológicas que se configuram como forças centrípetas e centrífugas, envolvendo o MOBRAL/PAF e a comunidade.

${ }^{2}$ O Movimento Brasileiro de alfabetização (MOBRAL) trata-se de movimento que abarcava subprogramas, mas neste texto estamos nos referindo ao subprograma Alfabetização Funcional (PAF). Daí a sigla MOBRAL/PAF. 
duo enquanto membro de um grupo" (HALBWACHS, 2004, p. 159). Por operações ideológicas entendemos tratar-se de mensagens subliminares, via linguagem verbal e imagética articuladas, com a finalidade de reificar valores.

\section{Contexto de implantação do MOBRAL/PAF}

O governo militar que se instaura em 1964 com a deposição do governo João Goulart, como aponta Coggiola (2001), se deu muito pelas influências externas, pois naquele momento estava se fortalecendo um quadro desfavorável aos interesses dos Estados Unidos (EUA). Esse autor mostra que, num sentido macro, o aspecto econômico e a luta pela hegemonia capitalista estavam em risco, pois, por volta de 1950, começava-se estabelecer uma possível união e criação de blocos independentes: "eixo não alinhado" de países que buscavam uma independência tanto do URSS como do próprio EUA, o que, na perspectiva norte-americana, precisava ser freado. Portanto, a Ditadura no Brasil não foi um movimento isolado, se atentarmos às ditaduras na América Latina.

A ditadura civil-militar ${ }^{3}$ no Brasil refere-se ao período histórico em que os militares, com o apoio de setores do empresariado e parte da sociedade civil, assumiram o poder e governaram o país durante vinte e um anos (19641985) - governo marcado por repressão, censura, perseguição política e frequentes ataques à democracia, tendo estreita ligação com os Estados Unidos. No contexto da guerra fria, a dicotomia entre comunismo versus mundo livre foi utilizada como álibi ideológico (COGGIOLA, 2001), pois, nessa engrenagem toda, o que está em jogo não é, necessariamente, a luta contra o comunismo, mas luta pelo poder, sobretudo, o poder econômico.

Nesse contexto sociopolítico, pela instituição do primeiro Ato Institucional (AI -I $)^{4}$, houve alteração da constituição, anulação dos mandatos legislativos e promulgação de eleições indiretas. O Brasil vivia um movimento de repressão e projetos tal como Movimento de Educação de Base (MEB); as Ligas camponesas, a sindicalização rural, a "Campanha de pé chão", o Movimento de Cultura Popular (MCP), entre outros, e o próprio Paulo Freire eram vistos como "uma perigosa ameaça aos fundamentos da 'Ordem' social interna, com

\footnotetext{
${ }^{3} \mathrm{O}$ termo 'ditadura civil-militar' alude aos setores empresariais, financeiros e oligarquias que concederam apoio financeiro decisivo para instauração da ditadura. Na verdade, não há consenso em relação à utilização do termo "ditadura civil-militar", pois se sabe que a Ditadura Militar efeti vou-se pelo domínio dos militares em que as Forças Armadas desempenharam o comando político e repressivo.

${ }^{4}$ O primeiro Ato Institucional (AI-1) foi editado pelos comandantes do Exército, Marinha, Aeronáutica como plataforma dos princípios do regime ditatorial, possibilitando suspensão de direitos políticos pelo prazo de dez anos; cassação de mandatos e outras providências (ALVES, 2005).
} 
sérios reflexos também no denominado 'equilíbrio' internacional de poder" (BEISEGEL, 1982, p. 258).

Com a instituição do AI-I buscou-se eliminar qualquer forma de oposição ao governo militar - medida radical para persuadir a população a aceitar os comandos do novo regime. Por volta de 1968, com a instituição do Ato Institucional cinco $(\mathrm{AI}-5)^{5}$, período denominado por muitos de "segundo golpe" houve repressão aos intelectuais, aos movimentos populares e à alfabetização de jovens e adultos numa perspectiva humanista. Nesse período, houve forte estreitamento de laços entre os EUA e o Brasil e as relações constituídas na ditadura, com o setor industrial, contribuíram com a instalação e expansão do capitalismo internacional.

No campo político educacional, o período da Ditadura foi marcado pela ligação com agências estrangeiras estadunidenses, em especial, com a United States Agency Development (USAID) que direcionava a educação brasileira nos moldes de consolidação do sistema capitalista e, nesse sentido:

Os acordos MEC-USAID cobriram todo o espectro da educação nacional, isto é, o ensino primário, médio e superior, a articulação entre os diversos níveis, o treinamento de professores e a produção e veiculação de livros didáticos. A proposta da USAID não deixava brecha. Só mesmo a reação estudantil, o amadurecimento do professorado e a denúncia de políticos nacionalistas com acesso à opinião pública evitaram a total demissão brasileira no processo decisório da educação nacional (CUNHA; GÓES, 1985, p. 33).

O Estado brasileiro programou reformas educacionais engajadas com a lógica do crescimento econômico, fortemente marcada pela não equidade de distribuição de renda. Assim, o governo brasileiro, sob a ótica de que estava atendendo as reivindicações sociais, buscava minimizar conflitos para "execução de seu modelo econômico de aceleração modernizadora e autoritária do capitalismo no Brasil” (FERREIRA; BITTAR, 2008, p. 334-335) e, para tanto, buscou cumprir acordos firmados junto à USAID.

\footnotetext{
${ }^{5}$ Com o segundo Ato Institucional (AI-2) editado em 13 de dezembro de 1968 o governo militar possibilitava ao Presidente da República: decretar recesso do Congresso Nacional, das As sembleias e das Câmaras de Vereadores; cassar mandato eletivos federais, estaduais e municipais e suspender os direitos políticos por dez anos; decretar intervenção nos estados, municípios e territórios; decretar o estado de sítio e prorrogá-lo; decretar o confisco de bens (COGGIOLA, 2001, p. 23).
} 
Esses acordos apontavam para uma política educacional fundamentada em concepções economicistas e produtivistas pautadas em ideologias de justificação, como aponta Romaneli:

As forças produtivas e as relações de produção características do capitalismo somente se concretizam e expandem num universo de valores, idéias, noções e doutrinas apropriadas. Nenhum Estado capitalista, portanto, pode prescindir de uma ideologia de justificação que dá conteúdo e substância à sua ação. Num país dependente, a essa ideologia, evidentemente alimentada pelas camadas ou grupos detentores do poder, corresponde, se não a ideologia alimentada pelas camadas dirigentes dos países centrais, pelo menos o reflexo dela (ROMANELI, 1984, p. 209, grifo nosso).

Desse modo, a UNESCO interveio nas políticas educacionais não só pelos altos índices de analfabetismo e a sua má repercussão a nível internacional, mas para conter movimentos de educação popular que vinham se fortalecendo numa visão político-pedagógica humanista. Nesse ínterim, em 1966 o governo ditatorial elaborou "o Plano Complementar em trabalho conjunto entre Conselho Federal de Educação, Ministério da Educação e Secretaria de Planejamento para estabelecer estratégias e reduzir os índices de analfabetismo" (OLIVEIRA; SOUZA, 1990, p. 18-19).

A partir de então, sob a égide da formação profissional daquele grupo que consistiria a força de trabalho para o mercado, efetivou-se pela Lei 5.692/71 a reforma dos antigos Ensino Primário e Secundário que passaram ser denominados Ensinos de $1^{\circ}$ e $2^{\circ}$ graus, tendo como premissa a escolaridade obrigatória de oito anos ( $1^{\circ}$ grau). $\mathrm{O}$ ensino de $2^{\circ}$ grau passa ter caráter de formação técnica profissional, mas essa profissionalização, proposta por essa reforma, não se consolidou em termos de qualidade devido baixos investimentos (GERMANO, 1993). Contudo, como afirma Frigotto (1989) vai além disso, pois trata-se de uma profissionalização que cumpre sua "produtividade improdutiva", visando fortificar a relação ideológica entre educação e estruturas socioeconômicas. Por essa lei, também, foi instituído o Ensino Supletivo que se instalou no campo educacional como modalidade de ensino - no sentido de suplência (BRASIL, 1971, p. 6). 


\section{Implantação do MOBRAL}

O Movimento Brasileiro de Alfabetização (MOBRAL) foi instituído pela Lei número 5.379, de 15 de dezembro de 1967 no governo do Presidente Arthur da Costa e Silva (BRASIL, 1967), mas que só foi implementado em 1970, por ocasião do governo de Emílio Garrastazu Médici. O MOBRAL, sob presidência Mário Henrique Simonsen e, posteriormente, de Arlindo Lopes Corrêa era composto por um conjunto de ações estratégicas, expandindo-se por todo país e envolvia: Programa de Educação Integrada (PEI); MOBRAL Cultural; Programa de Profissionalização e Programa de Alfabetização Funcional (PAF) - foco de nossa atenção nesse estudo.

O MOBRAL/PAF tinha como objetivo erradicar o analfabetismo do Brasil, num espaço curto de tempo, e se apresentava como um programa cuja meta era "[...] conduzir a pessoa humana a adquirir técnicas de leitura, escrita e cálculo como meio de integrá-la a sua comunidade, permitindo melhores condições de vida" (MENEZES; SANTOS, 2002, s/p). Trata-se de uma concepção de educação que se insere num movimento amplo em que os processos de ensino são considerados, em si mesmos, com supostas possibilidades de preparar indivíduos para a marcha do progresso:

Isto é, educação aparece não só como consumo, mas como um investimento de enorme rentabilidade, individuais e sociais, com altas taxas de retorno, que variam de acordo com os níveis educacionais. Conclui-se nesta análise que uma população mais escolarizada será uma população com níveis mais altos de tolerância social e convivência, mais produtivo e competitivo nos mercados nacional e internacional. Em suma, para dizêlo no jargão sociológico, quanto mais educação, melhor sociedade, composta de indivíduos mais completo, responsável e produtivo (TORRES, 2001, p. 24 trad. nossa).

Por conseguinte, a educação concebida no período ditatorial tinha caráter tecnicista e visava à adaptação do aluno ao meio profissional. Como lembra Jannuzzi (1979, p. 54), refletindo sobre o pensamento da época: “O analfabetismo devia ser erradicado, porque o analfabeto era visto como um dos grandes obstáculos ao desenvolvimento do país" e, em paralelo, nascia naquele momento a noção de Alfabetização funcional, ou seja, a ideia da formação de sujeitos para exercerem uma função na sociedade.

O governo, na perspectiva da educação como salvacionismo, viu na alfabetização uma possibilidade de encaminhar homens e mulheres para o merca- 
do de trabalho - público que precisava ser alfabetizado "[...] para mais facilmente receber as informações e o treinamento que o permitiam desempenhar o papel de que lhe é reservado no desenvolvimento" (JANUZZI, 1979, p. 54).

A alfabetização desse programa estava vinculada à esfera econômica e às demandas do projeto hegemônico do capital que prima em disciplinar os sujeitos para a vida produtiva, agindo na / para transformação intelectual, cultural e ética dos envolvidos (KUENZER, 2002). Assim, em seu documento base, o MOBRAL/PAF esclarece a noção de alfabetização funcional adotada:

A alfabetização Funcional preconizada pelo MOBRAL é aquela que propicia a adolescente e adultos a aplicação prática e imediata das técnicas de ler, escrever e contar, permitindo-lhes buscar melhores condições de vida.

Ela é funcional porque leva o aluno a descobrir sua função, o seu papel no TEMPO e no ESPAÇO em que vive. Desenvolve a criatividade, cria hábitos de higiene e saúde, ensina o aluno a viver na comunidade, leva-O a conhecer seus direitos e deveres. Procura transformar o Homem, portanto, em agente e beneficiário do processo de desenvolvimento. $^{6}$

[...] e com esse programa espera-se criar possibilidades de semi-qualificação profissional que, nesta fase, será mais voltada para o aproveitamento e desenvolvimento de habilidades que influem na subsistência da família (BRASIL, Documento base, 1975, p. 41, grifo nosso).

\section{O MOBRAL e a comunidade}

Do ponto de vista do funcionamento, havia uma espécie de força centrípeta atuando no Mobral/PAF - programa marcado pela articulação com órgãos externos que, em alguma medida, colaboravam para sua existência e funcionamento em forma de convênios ou participação espontânea, cedendo espaços, divulgando o movimento, dando apoio jurídico, financeiro, entre outras participações, conforme o número de órgãos envolvidos, demonstrados na figura a seguir:

\footnotetext{
${ }^{6} \mathrm{Na}$ verdade, essa assertiva trata-se de um efeito ideológico, pois o analfabeto não era o agente, pois era manipulado e, muito menos, beneficiário do desenvolvimento.
} 
Figura 1 - Forças centrípetas e a comunidade

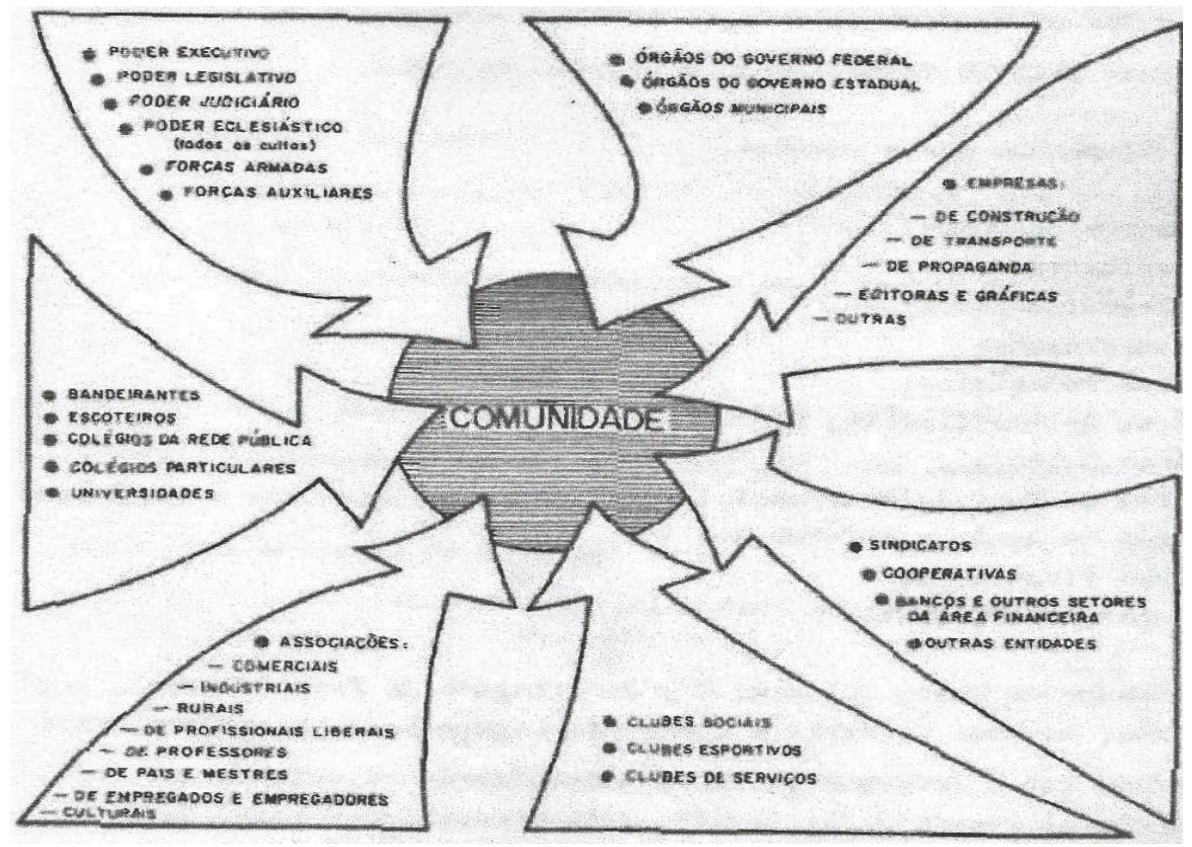

Fonte: (BRASIL, Documento base, 1975, p. 19)

Por outro lado, do ponto de vista da comunicação e interação com a comunidade, nota-se um movimento contrário, uma espécie de força centrífuga, atuando de dentro para fora, via recursos midiáticos - um poder ideológico altamente estruturado que se desdobrava por meio de símbolos, frases de efeitos, muito comuns aos sistemas autoritários cujo intento comunicativo é dar instruções; é impor ideias do grupo de poder por meio de estratégias direcionadas à comunidade. A esse respeito, Paulo Freire expressa: “[...] a propaganda, os slogans, os depósitos, os mitos são instrumentos usados pelo invasor, para lograr seus objetivos" (FREIRE; GUIMARÃES, 1987, p. 42).

Nesse sentido, foram muitos os slogans utilizados para enaltecer o Brasil e criar uma memória social, marcada pela euforia e ufanismo: "Ninguém segura este país", "Pra frente Brasil", "Brasil: ame-o ou deixe-o", entre outros. São slogans com caráter nacionalista por meio dos quais se cria o ideal de progresso do período ditatorial militar e a conclamação para o esforço individual: "Brasil, conte comigo", "Você constrói o Brasil", como se o esforço individual, a dedicação, a renúncia fossem, por si só, responsáveis pelo progresso de uma nação. Enquanto prática político-administrativa 
O slogan político mais do que uma prática publicitária, uma marca que, de alguma forma, identifica um governo, diferenciando-o dos outros, se constitui um código de conduta moral, numa síntese de regulamento que procura definir tipos de subjetividade. Ou seja, os slogans políticos, por serem uma espécie de monumento, que se apresenta nos mais diversos textos oficiais - editais, ofícios, outdoors de obras públicas, chamadas radiofônicas e televisivas etc, - constroem a necessidade de os indivíduos se inserirem em determinados padrões de comportamento (FONSECASILVA; POSSENTI, 2007, p. 174).

Essa ação midiática revela as forças políticas dominantes que se caracterizam não só pelas "mãos de ferro", mas por um sistema comunicativoideológico que seduz, que comove, conclama e, também, ordena:

Figura 2 - Propaganda do governo

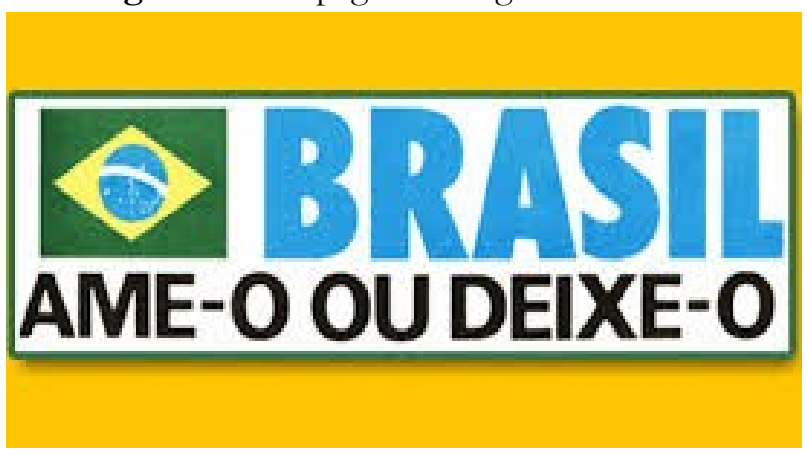

Fonte: https://www.google.com/search?q=propagandas+regime+militar

Figura 3 - Propaganda do governo

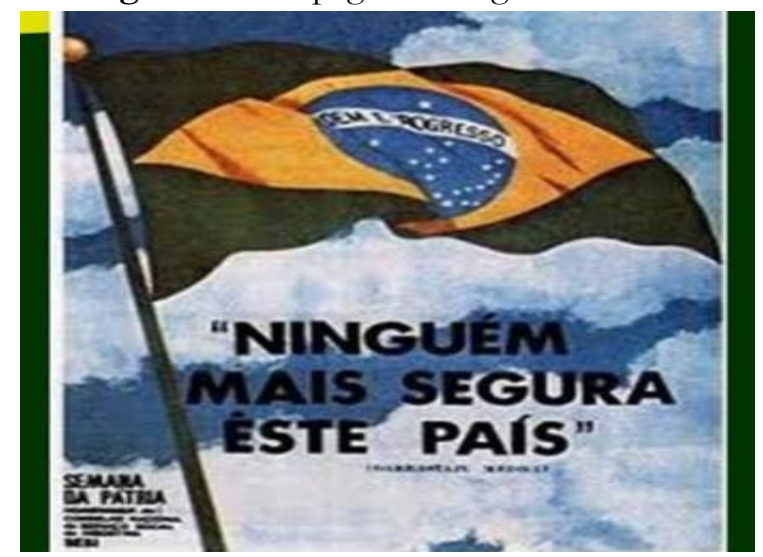

Fonte: https://www.google.com/search?q=propagandas +regime+militar 
O governo militar, por meio do MOBRAL/PAF, empenhou-se na tentativa de envolvimento da comunidade e, pela iconografia, apresentamos fragmentos da influência do regime ditatorial no aspecto cultural, quando utilizava músicas, poemas, propagandas, dirigidas à comunidade brasileira. Esses recursos funcionavam como forma de sedimentar a memória dos valores do Regime e, por outro lado, era uma forma de incentivar o "compromisso" com o país, bem como para a "responsabilidade" de procurar pessoas analfabetas e inseri-las no programa, como também alfabetizá-las por conta própria, em suas próprias casas.

No conjunto de propagandas enaltecendo o país, e o próprio MOBRAL/PAF, vai se consolidando o dizer do Estado: engajamento e responsabilidade da comunidade. Na verdade, nesse jogo de signos, nota-se um efeito de distorção - muito comum no discurso autoritário que subverte a ideia de responsabilidade. Nas figuras 4 e 5 logo a frente, o texto base, agregado à imagem de uma digital, apresenta o cidadão como responsável pela existência de um possível analfabeto. Nesse texto, por um lapso contraditório, revela-se aquilo que sempre é ocultado: o fato de que muitos não têm chance alguma. $O$ texto da propaganda revela: Dê uma chance a quem nunca teve nenhuma, conforme figuras abaixo:

Figura 4 - Propaganda do MOBRAL

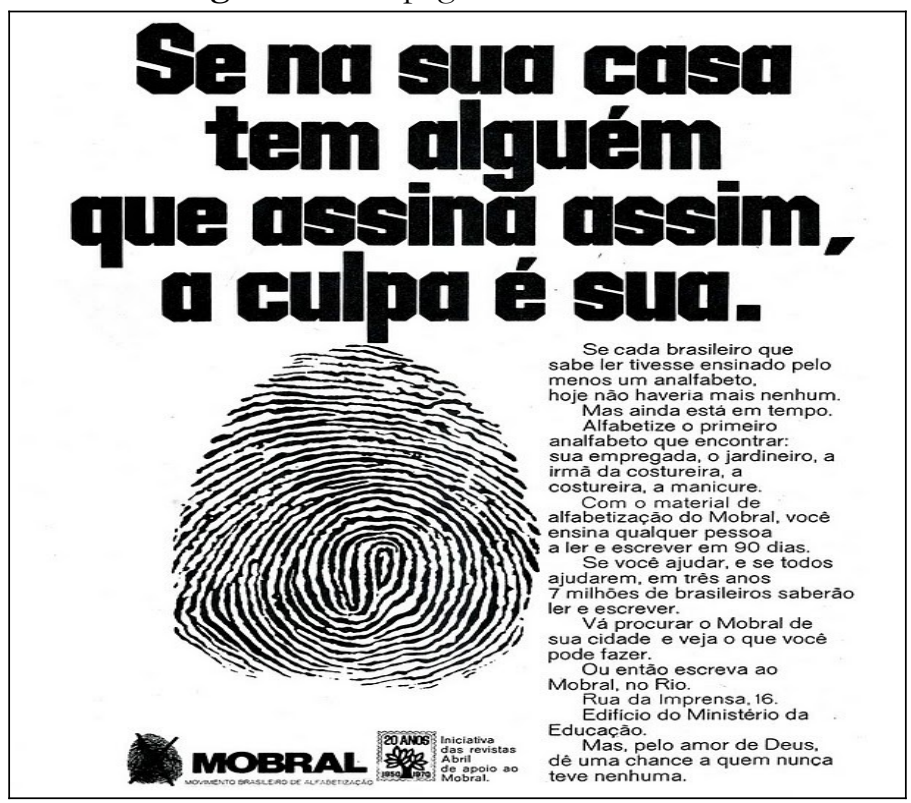

Fonte: Domínio Público 
Figura 5 - Propaganda do MOBRAL

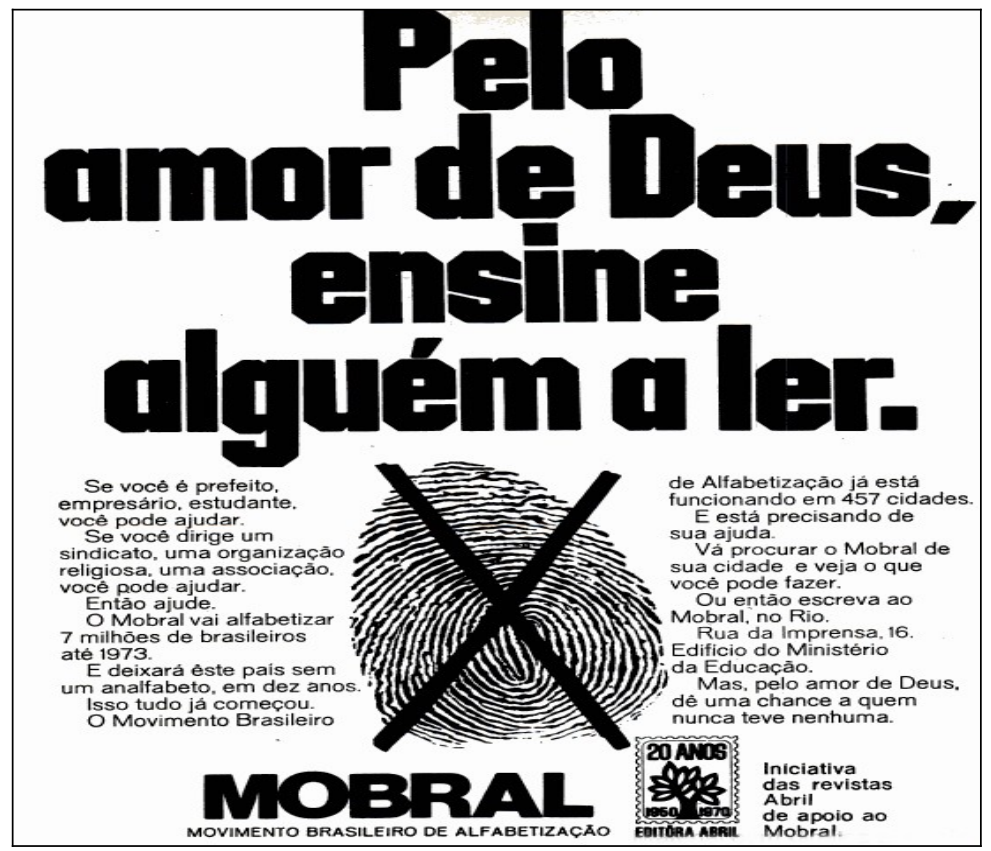

Fonte: https://www.propagandashistoricas.com.br/2018/06/propagandaantiga-mobral.html

A figura 4 traz, em primeiro plano, a ideia incisiva de que se tem analfabeto a culpa é sua - do cidadão comum que, nesse momento, além de seu empenho, dedicação e renúncia para o progresso do país, haveria de atuar como recrutador e alfabetizador, pois, afinal, esse homem e essa mulher precisavam atender a quem nunca teve uma chance - ideia que se apresenta, em certa medida, escamoteada, ao final do texto.

$\mathrm{Na}$ figura 5, observa-se no discurso um apelo à memória religiosa, e a digital - representativa do analfabetismo - já riscada, passando a ideia de consolidação da campanha contra o analfabetismo e, ao final, reitera-se a necessidade de dar uma chance a quem nunca teve.

Nesse esforço salvacionista, já bem retratado pela literatura, outra forma de apelo à comunidade, no sentido de sensibilizá-la, diz respeito à utilização de músicas e jingles, pois "não há produção cultural que não empregue materiais impostos pela tradição, pela autoridade ou pelo mercado e que não esteja submetida às vigilâncias e as censuras de quem tem o poder sobre as palavras e os gestos" (CHARTIER, 1960, p. 137). 
Nesse período, foram utilizadas muitas propagandas para divulgação maciça via rádio e TV, pois o MOBRAL contava com vultuosos recursos financeiros. Abaixo temos a música "Você também é responsável" da dupla Dom e Ravel - faixa do disco "Terra Boa” pela gravadora RCA VICTOR, em 1971. Com essa música buscava-se chamar os brasileiros para a responsabilidade na construção do "Brasil Grande" - slogan fortemente divulgado:

Figura 6 - Música do MOBRAL

\begin{tabular}{|} 
Você também é responsável \\
Eu venho de campos, subúrbios e vilas, \\
Sonhando e cantando, chorando nas filas, \\
Seguindo a corrente sem participar, \\
Me falta a semente do ler e contar \\
Eu sou brasileiro anseio um lugar, \\
Suplico que parem, prá ouvir meu cantar \\
Você também é responsável, \\
Então me ensine a escrever, \\
Eu tenho a minha mão domável, \\
Eu sinto a sede do saber \\
Eu venho de campos, tão ricos tão lindos, \\
Cantando e chamando, são todos bem vindos \\
A nação merece maior dimensão, \\
Marchemos prá luta, de lápis na mão \\
Eu sou brasileiro, anseio um lugar, \\
Suplico que parem, prá ouvir meu cantar
\end{tabular}

Fonte: https://www.vagalume.com.br/dom-e-ravel/voce-tambem-e-responsavel.html

Os cantores Dom e Ravel, ambos falecidos, tiveram sua trajetória artística marcada pela ligação, autorizada ou não, ao governo militar. No início dos anos setenta, esses cantores lançaram a hit: "Eu te amo meu Brasil" - música ufanista ligada a temas tais como mulher brasileira, futebol, carnaval, entre outros e foi utilizada pela instância federal nas propagandas oficiais, sendo considerada o hino do governo Militar. 
Por sua vez, a canção "Você também é responsável" foi gravada em 1969 e um ano depois já estava associada ao MOBRAL, sendo utilizada pelos governantes como hino desse programa.

O poema apresenta forte apelo emocional e casava com os ideais propagados pelo governo militar, cujos versos, de início, retratam os sujeitos a quem o MOBRAL/PAF atendia: homens e mulheres dos quatros cantos do Brasil - pessoas humildes, dos campos, vilas; povo sofrido que, para os dirigentes do país, estaria à margem do progresso e sem oportunidades por não saber ler e escrever.

Na sequência, o poema traz o ápice de vulnerabilidade desse 'Ser não leitor' e seu grito de súplica, representado pelos versos:

Eu sou brasileiro anseio um lugar, Suplico que parem, prá ouvir meu cantar

Você também é responsável

Então me ensine a escrever,

Eu tenho a minha mão domável

(DOM E RAVEL, 1971)

O elemento "mão domável" aparece enquanto metáfora para referir o homem dócil e a alfabetização entra como elemento de domesticação o que possibilitaria ao homem e à mulher serem agregados, como um soldado numa causa nacional, de arma em punho - o lápis:

A nação merece maior dimensão,

Marchemos prá luta, de lápis na mão

Eu sou brasileiro, anseio um lugar,

Suplico que parem, prá ouvir meu cantar

(DOM E RAVEL, 1971)

Trata-se de versos que reverberam memórias consensuais ligadas à nação, ao patriotismo, ao progresso, à educação - pela ajuda e envolvimento da comunidade, sendo esse movimento de alfabetização pensado como o salvador da pátria, como também se observa na canção abaixo: 
Figura 7 - Música do MOBRAL

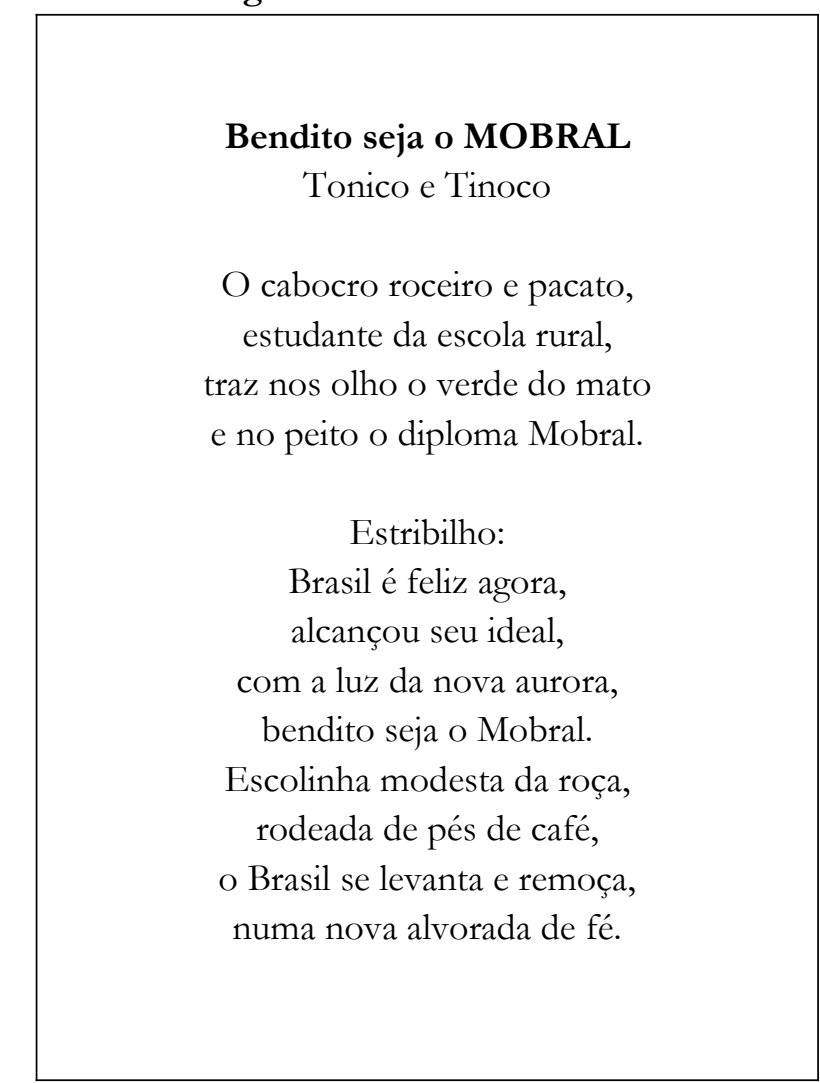

Fonte: https://www.letras.mus.br/tonico-e-tinoco/89164/

"Bendito seja o Mobral" é uma canção da dupla sertaneja Tonico e Tinoco que também sustenta ideias ufanistas tão presentes no governo militar. Em seus versos encontram-se a idealização do sucesso, do progresso - via alfabetização, como se uma vida melhor para o brasileiro e a brasileira fosse direta e, exclusivamente, garantida pela educação. A utilização dessa música, entre outras, se dá também com o intento de camuflar o tipo de alfabetização oferecida.

Nessa canção, o homem dócil, orgulhoso do seu país invoca a religiosidade, pois em Halbwachs (2004) vimos que a religião é um quadro social da memória muito presente e, nesse caso, vemos versos abençoando o movimento de alfabetização:

\author{
Brasil é feliz agora, \\ alcançou seu ideal, \\ com a luz da nova aurora,
}


São versos simples de um poema musicado que faz parte do movimento musical denominado "Folkcomunicação" (BELTRÃO, 1980), músicas pertencentes ao cancioneiro popular que passam um sentimentalismo exagerado, frente a um porvir de glórias:

o Brasil se levanta e remoça numa nova alvorada de fé. (TONICO E TINOCO, 1971)

Nessa perspectiva, outra canção bastante divulgada naquele momento histórico, foi a canção do grupo musical Os Incríveis: "Pra Frente Brasill"

Noventa milhões em ação

Pra frente Brasil, no meu coração

Todos juntos, vamos pra frente Brasil

Salve a seleção!!!

De repente é aquela corrente pra frente, parece que todo o Brasil deu a mão!

Todos ligados na mesma emoção, tudo é um só coração!

Todos juntos vamos pra frente Brasil!

Salve a seleção!

Todos juntos vamos pra frente Brasil!

Salve a seleção!

Gol!

(OS INCRÍVEIS, 1970)

Essa canção apela para a memória social do futebol como um bem nacional e, por meio da seleção brasileira, trazia a ideia de unidade nacional, de pátria ideal e harmônica: "tudo é um só coração; Todos juntos vamos pra frente Brasil”, de modo que a realidade dos cidadãos e cidadãs que não estavam indo pra frente, tampouco indo na mesma direção fica ocultada nos versos. 


\section{Considerações finais}

Por época da implantação do MOBRAL/PAF foi divulgado um arsenal midiático amplo na divulgação desse programa. Nessas investidas, vemos o apelo a uma memória social (HALBWHACS, 2003, 2004) baseada em construtos sociais como pátria, nação, educação, religiosidade, fé, entre outros, que ideologicamente são acessados para conclamar a dedicação, a renúncia, o esforço individual, atributos que, naquele momento, representavam um padrão de comportamento ideal que, supostamente, seria responsável pelo progresso do país.

Isso nos faz lembrar Gramsci (1978) quando, ao falar dos aparelhos ideológicos hegemônicos do Estado, propõe que nenhum estado totalitário se sustenta somente pela coerção, porque ele sempre vai investir no aspecto ético, moral e, inclusive, estético para consolidação de um Ethos agregador cuja capilaridade se consolida por sistemas ideológicos ético-políticos tais como: meios de comunicação, arte, educação etc.

Vimos que os slogans trazem uma linguagem autoritária, imperativa - revestida de ardor e ufanismo; as músicas, os jingles caracterizam-se pelo tom apelativo e emotivo, buscando agregar a comunidade pelo efeito estético. Portanto, o contexto sociopolítico da implantação do MOBRAL/PAF, bem como sua relação com a comunidade - via forças centrípetas e centrífugas, apontam a constituição de interesses políticos e econômicos de grupos que buscam manter a dominação e o poder perante determinados setores sociais.

\section{Referências}

ALVES, M. H. M. Estado e oposição no Brasil: (1964-1984). Bauru: Edusc, 2005.

BEISEGEL, C. de R. Política e educação popular: a teoria e a prática de Paulo Freire no Brasil. São Paulo: Ática, 1982.

BELTRÃO, L. Folkcomunicação: a comunicação dos marginalizados. São Paulo: Cortez, 1980.

BRASIL. Lei no 5.379, de 15 de dezembro de 1967. Provê sobre a alfabetização funcional e a educação continuada a adolescentes e adultos. Diário Oficial da União, Senado Federal online. Disponível em: < $\underline{\text { http://legis.senado.gov.br/le- }}$ gislacao/ListaPublicacoes.action?id=117865 > . Acesso em: 01 maio 2017. 
. Lei $\mathrm{n}^{\circ}$ 5.692, de 11 de agosto de 1971. Fixa as diretrizes e bases para o ensino de $1^{\circ}$ e $2^{\circ}$ graus, e dá outras providências. Diário Oficial da União, Brasília, 12 agosto 1971.

. Ministério da Educação e Cultura. MOBRAL. Fundação Movimento Brasileiro de Alfabetização. Documento Base. 7.ed. Rio de Janeiro: Abril Cultural, 1975.

CHARTIER, R. A história cultural entre práticas e representações. Lisboa: DIFEL, 1960.

COGGIOLA, O. L. A. Governos militares na América Latina. São Paulo: Contexto, 2001.

CUNHA, L.A.; GÓES, M. O golpe na educação. Rio de janeiro: Jorge Zahar, 1985.

DOM E RAVEL. Você também é responsável. 1971. Disponível em: <https://www.vagalume.com.br/dom-e-ravel/voce-tambem-e-responsavel.html>. Acesso em: 10 abr. 2019.

DOMÍNIO Público. Figura Mobral. Disponível em: $<$ http://1.bp.blogspot.com/-acwJuF1CsK0/TpGqf kLUUI/AAAAAAAAEVg/x5UiTMULhwY/ s1600/Mobral.jpg >. Acesso em: 10 abr. 2019.

FERREIRA, J. A.; BITTAR, M. Educação e Ideologia tecnocrática na ditadura militar. Cadernos CEDES, Campinas, v. 28, n. 76, p. 333-335. 2008. Disponível em: < http://www.scielo.br/pdf/ccedes/v.28n76/a04v2876.pdf $>$. Acesso em: 14 de maio, 2019.

FREIRE, P.; GUIMARÃES, S. Aprendendo com a própria história. Rio de Janeiro: Paz e Terra, 1987.

FONSECA-SILVA, M da C; POSSENTI, S. (org.). Mídia e rede de memória. Vitória da Conquista: Ed. UESB, 2007.

FRIGOTTO, G. A produtividade da escola improdutiva: um (re)exame das relações entre educação e estrutura econômico-social. São Paulo: Cortez, 1989. GRAMSCI, A. Os intelectuais e a organização da cultura. Rio de janeiro: Civilização Brasileira, 1978.

GERMANO, J. W. Estado militar e a educação do Brasil. São Paulo: Cortez, 1993.

HALBWACHS, M. A memória coletiva. Tradução: Beatriz Sidou. São Paulo: Centauro, 2003. 
. Los marcos sociales de la memória. Tradução: Manuel A. Baeza y Michel Mujica. Barcelona: Antrophos Editorial; Concepcion: Universidad de La concepcion; Caracas: Universidade Central de Venezuela, 2004.

JANNUZZI, G. S. M. Confronto pedagógico: Paulo Freire e o Mobral. São Paulo: Cortez; Moraes, 1979.

KUENZER, A. Z. Exclusão includente e inclusão excludente: a nova forma de dualidade estrutural que objetiva as novas relações entre educação e trabalho. In: SAVIANI, D.; SANFELICE, J.L.; LOMBARDI, J.C. (org.). Capitalismo, trabalho e educação. Campinas: Autores Associados, 2002.

MENEZES, E. T. de; SANTOS, T. H. dos. "Mobral (Movimento Brasileiro de Alfabetização)" (verbete). EducaBrasil. Dicionário Interativo da Educação Brasileira. São Paulo: Midiamix, 2002. Disponível em: $<\underline{\text { http://www.educabra- }}$ sil.com.br/eb/dic/dicionario.asp?id=130>. Acesso em: 1 maio 2015.

OLIVEIRA, L. B. e SOUZA, S. TA alfabetização no MOBRAL: métodos e materiais didáticos. (Uberlândia/MG,1970-1985). Revista Brasileira de Alfabetização, 100, 32, 1990.

OS INCRÍVEIS. Pra Frente Brasil. 1970. Disponível em: < $\underline{\text { https://www.va- }}$ galume.com.br/os-incriveis/pra-frente-brasil.html>. Acesso em: 10 abr. 2019. TONICO E TINOCO. Bendito seja o MOBRAL. 1971. Disponível em: $<$ https://www.letras.mus.br/tonico-e-tinoco/89164/>. Acesso em: 10 abr. 2019.

TORRES, C. A. Grandezas y miserias de La educación latinoamericana Del siglo veinte. In: Paulo Freire y La agenda de La educación latinoamericana em el siglo XXI. Buenos Aires: CLACSO, 2001. 